\title{
Building Enterpreneurship Competence: The Evidence of Edotel Effectiveness
}

\author{
Pardjono \\ Universitas Negeri Yogyakarta \\ Yogyakarta, Indonesia \\ pardjono@uny.ac.id)
}

\author{
Erfin Dwi Priana \\ SMK Negeri 4 Surakarta \\ Surakarta, Indonesia \\ erfin_19@yahoo.co.id
}

\begin{abstract}
This study aimed at revealing the roles of the Educational Hotels (Edotel) in developing the entrepreneurial competence and the factors affect the formation of entrepreneurship attitude of students of hospitality accommodation program at Vocational High School (VHS) in Yogyakarta. This research employed an explanatory model of mixed (quantitative and qualitative) approach of research method. For quantitative research the 155 year XII hospitality accommodation students were assigned as population. Furthermore, 18 students with the highest entrepreneurial scores were then selected for qualitative inquiry. Data were collected using test, questionnaire, and interview. Quantitative data were analyzed by percentage and qualitative data were analyzed using cyclical model of Miles and Huberman. The result shows that Edotel administered positive impacts on improving: (1) entrepreneurship knowledge of students, (2) student entrepreneurship attitudes which the strongest is leadership and responsibility, (3) for entrepreneurship skills, the strongest are conceptual skills and decision-making skills. The qualitative investigation found that family environment, social environment, personal ability, and student's industrial attachment experience are estimated affect on the formation of students entrepreneurship attitude.
\end{abstract}

Keywords: entrepreneurship; internship program; vocational hospitality

\section{INTRODUCTION}

The increasing number of unemployed in Indonesia, according to Indonesian Minister of Worker and Transmigration Hanif Dhakiri, is due to two possibilities. The first is an unavailability of jobs vacancies and the second is low quality of workforce so that worker candidates have difficulty occupying the available job vacancy. (http://news.detik.com/berita/3064402/, accessed on 6 November 2015). Inadequate availability of employment will be resolved by itself if national economic growth is above $6 \%$ because it will be growing new jobs. While the low quality of worker can be overcome by improving their competence by means of educational programs and trainings.

It is known that the number of entrepreneur in Indonesia is low, that is only $1.5 \%$ of the total population. It is a quite low proportion when compared to neighboring countries, such as Malaysia and Singapore which reaches $5 \%$ of the total population. The proportion of enterpreneur of only $1.5 \%$ over the population is not likely sufficient to create job opportunity for employment. (Http://www.timlo.net/baca/60105/, accessed on November 4, 2013).
There has been many attepts to solve the unemployment, and the Indonesian government efforts to reduce unemployment in the formal sector is currently under way. While for the informal sector, it is given more space to develop as a means of becoming an emergency remedy in overcoming unemployment. To increase employment in the formal sector are commonly conducted through education especially vocational education. Vocational Education is normally organized to develop students' career in certain areas of vocational expertise for being able to work [1] [2]. As it is mentioned [3] that Vocational education as an education that provides supplies to the students for earning living. Vocational Education is also defined as education that prepares the students to become productive workers [4].

In 1995, The National Movement of Socializing and Entrepreneurship has been launched by the government of Indonesia echoing the importance of entrepreneurship. By the movement, a massive effort can be made and the government may use all the resources to support the accomplishment of this movement policy. One of government's important resources is education, including vocational education and training.

The official data of the Central Bureau of Statistics (BPS) the number of open unemployed by education in February 2015 reached 7.4 million people. Below is the data of open unemployment recorded by BPS.

TABLE 1. Open Unemployment Rate (OUR) of 15 Years of Age or Upper Based on Education, in 2015.

\begin{tabular}{|c|l|r|}
\hline No & \multicolumn{1}{|c|}{ Education of } & Number of People \\
\hline 1 & Never go to school & 124,303 \\
\hline 2 & $\begin{array}{l}\text { Have not finish Elementary } \\
\text { School }\end{array}$ & 603,194 \\
\hline 3 & Elementary School & $1,320,392$ \\
\hline 4 & Junior High School & $1,650,387$ \\
\hline 5 & Senior High School & $1,762,411$ \\
\hline 6 & Vocational High School & $1,174,366$ \\
\hline & Diploma I/II/III & 254,312 \\
\hline 8 & University & 565,402 \\
\hline & Total & $7,454,767$ \\
\hline
\end{tabular}

Data on table 1 shows that number of unemployed of vocational high school (VHS) graduate is high, i.e. reaching $1,174,366$ people. The data indicates that although VHS graduates have already been trained to develop competence in particular vocational field in order to work, however 
unemployment of vocational high school graduates are remain high. It may also be the result of vocational education that generally tend to prepare students to become workers in a company or in a productive institution rather than job creators. It is therefore appropriate that the government has a concern for the shortcomings of new entrepreneurs by establishing a movement in entrepreneurship education.

The notion of entrepreneurship is [5] that "the process of creating time and effort, assuming the accompanying financial, psychic, and social risks, and receiving the resulting rewards of monetary and personal satisfaction and independence" [6]. It is believed that entrepreneurship begins because of the phenomenon of supply push, a push that forces entrepreneurs to be forced to take risks. The entrepreneurship is a capability in creating somethings [7].

Entrepreneurship cannot be learned simply by memorizing the theory but by the real practice. The subject of entrepreneurship in VHS aims to establish entrepreneurial competencies that are aligned with the field of vocational skills of which the students are studied. The entrepreneurial education or learning aims to train and develop a range of students' knowledge, skills, values, and understanding on the need for creativity [8]. Similarly, the entrepreneurial learning at all levels has the main objectives, e.i (1) raising learners' awareness that entrepreneurs as career choices, (2) promoting the development of personal qualities relevant to entrepreneurship, such as creativity, risk-taking, and responsibility, and (3) provide the technical and business skills necessary to start and run a new business [9].

Entrepreneur must have knowledge, skills, and attitudes [10], for which these aspects ditermine success. None of the three can be omitted. There are several factors that allegedly related to the formation of entrepreneurial spirit, e.i. the background of parent work, family culture, and the process of education and training in schools [11]. The importance of integrated enterpreneurship education within vocational education is in line with the mission and goal of vocational education and therefore will even improve its effectiveness.

The objectives of VHS are: 1) preparing learners to work independently or to fill job vacancies in the business as well as in the industries as a middle-level workforce, in accordance with their vocational field and expertise; 2) equipping students to develop a career, tenacious and persistent to compete, and develop a professional attitude in the field of vocational, and 3) equipping learners with science and technology to promote them to higher education. These strategic role of VHS in preparing workforce and developing entrepreneurship, therefore, becomes the government's priority in the field of education, as stated in the Outlines of the Vocational Education Program for 2014-2019. It has been stated that the development of the education sector is directed towards the achievement of economic growth that supported by the availability of quality human resources. The quality human resources are the people who are able of createing employment as entrepreneurship while also fulfilling labor needs.
Concerning this entreprenuership future goal, it has been explicitly stated in the Strategic Plan of Directorate of Vocational Development that VHS graduates are targeted $35 \%$ to work independently, $40 \%$ work in according to their field, $5 \%$ work abroad, and $20 \%$ study to higher level of education.

The Strategic Plan the Ministry of National Education 2010-2014, ordered all vocational schools provide training and coaching for students entrepreneurship development. To implement the program, the VHS improve quality of enrepreneurship subject learning by integrating its learning into the learning of vocational subjects. The model of integrated learning enterpreneurship and vocational subjects had been proven effective to develope entrepreneurship such as in the vocational field of building construction [12] and in the field of culinary tourism [13]. Strengthening entrepreneurship learning aims to provide knowledge, attitude, and entrepreneurship skills to prepare learners to create jobs, and alleviate unemployment. The further impact of this strategic program can reduce poverty, prevent economic downturn and can politically change the dignity of an independent state [14].

Entrepreneurship learning in VHS is divided into learning theory and practice in schools and intership program in related industries or in the world of work. The intership program means to provide practical experience of enterpreneurial on actual activities. The practical program for internships of these VHS students has been disigned and in order to facilitate them to implement apprenticeship programs, the government builds business unit within the school environment. It is intended for efficiency because it will be easily reached by students. For this reason the government built Edotel to facilitate the apprenticeship of vocational students who take the skills of hospitality accommodation. Entrepreneurial opportunities in tourism in Yogyakarta is quite good because Yogyakarta is a national and international tourist destination after Bali. It is therefore appropriate that the VHS of tourism gets a favorable attention from the government. There are several similar facilities for other cluster of vocation which have been built by the government such as Teaching Factory, Business Center, or Incubator Unit [14].

The internship enterprenership program in the Edotel is intended to equip students with knowledge, skills, and entrepreneurial attitudes in tourism. There are currently three Edotel in Yogyakarta Special Region that built at VHS 4 in Yogyakarta, VHS 6 in Yogyakarta, and VHS 1 in Kalasan. In addition to being a means of learning entrepreneurship and vocational skills, Edotel also serves as a business unit that can generate benefits for schools.

The Edotel and internship programs are aligned with the principle that vocational education will be efficient if the environment in which learners are trained is a replica of the environment in which they will work. Vocational education is effective if the training tasks are performed in the same manner, tools, and machines as required in the job and vocational education will be effective if practicing thinking and working habits such as in work and industries [15]. Several studies have shown that there are learning activities in 
the world of work on improving students 'readiness to work [16], and also on students' self-confidence [17]. The problem then arises, how the apprenticeship program in Edotel impact on the development of entrepreneurship competence in hospitality accommodation of vocational students. Furthermore, which factors strongly influence the development of entrepreneurial competence through internship program at Edotel.

\section{RESEARCH METHODS}

\section{A. Approach and Type of Research}

This study used an explanatory mixed approach of research that is quantitative and qualitative approach. The quantitative approach was employed to find impact of internship program of Edotel on student's competence, then qualitative investigation approach was used to explain what, how, and why the positive impact was happened. The quantitative inquiry approach used a descriptive, while qualitative approach used case study model.

\section{B. Place of Study}

This research was conducted in the Edotel at VHS 4 Yogyakarta, VHS 6 Yogyakarta, and at VHS 1 Kalasan. Time of research and data retrieval from August 2015 to February 2016.

\section{Population and Research Subject}

The population was the year XII students of the hospitality accommodation of VHS in Yogyakarta who had accomplished his/her industrial attachment program. Number of population was 155 students then all members of the population was assigned as sample. Subject for qualitative investigation was determined based on the criteria of student's score of competence. The 6 (six) highest score of each school were assigned to become subject of qualitative investigation, so that there were 18 (eighteen) students for three schools.

\section{Method and Instrument of Data Collection}

This study investigate student's entrepreneurship competence after taking internship program in Edotel. There were three sub-variables of competence, i.e. knowledge, attitude, and skills. Entrepreneurial knowledge is defined as the ability to conceptualize and process resources including information, technology, ways, and skills into a new innovation of way, product, method and of marketing profit. Students' entrepreneurship knowledge includes: selfknowledge and practical knowledge. The self-knowledge is knowledge of planned business in hospitality that will be running. The practical knowledge is the knowledge how to run the business, including knowledge in business design, business management, business processing, bookkeeping, business administration, and business marketing.

Entrepreneurial attitude is a personality figure of a person who is born through the physical movement and response of one's mind toward entrepreneurship. The entrepreneurial attitude covers self-confidence, honesty, and leadership, creative, innovative, discipline, responsibility, independent, and decision making.

Entrepreneurship skills are the abilities of running business to achieve success. Running business is not only influenced by knowledge, and entrepreneurial attitude, but also required the mastery of entrepreneurial skills. The entrepreneurial skills consist of technical skills of the hospitality, conceptual skills, decision-making skills, and time-managing skills.

Data were collected using test, questionnaire, and interview. The test to measure knowledge of tourism entrepreneurship uses the validated instrument through expert judgment as well as through empirical validation. The ITEMAN software was used to analyze and the result stated that the instrument was valid. Questionnaires were used to collect attitude and skills and validated empirically and the questionnaire was valid and reliable. To collect qualitative data, depth interviews were used with an interview guide and audio recorder.

\section{E. Data Analysis Technique}

Quantitative data of acquired knowledge, attitude, and entrepreneurial skill were then analyzed by using quantitative descriptive analysis which aims to give a realistic figure of Edotel's effectiveness in developing entrepreneurial knowledge, attitude, and skill. Presentation of data in percentage is further described and summarized based on specified criteria. The categorization used three categories, that is effective, quite effective and not effective Criterion from Azwar[18].

To find out what factors are expected to affect the high competence of student entrepreneurship then conducted a deeper analysis using qualitative approach with case study model. Yin [19] states "case study allows an investigation to retain the holistic and meaningful characteristics of real life events" (p.14). Qualitative data are explored by conducting indepth interviews related to the influence of family environment, education, personal abilities, age, and student working experience in Edotel and of industrial attachment experience. Qualitative data are analyzed using four steps: interview transcript, reduction, classification, and conclusion. [20]

\section{RESEARCH RESULT AND DISCUSSION}

\section{A. Research Results}

The results show that Edotel has a positive impact on helping students to improve: (1) entrepreneurial knowledge reaches above $70 \%$ students. In more detail for VHS 4 Yogyakarta reached $73.77 \%$; For VHS 6 Yogyakarta reached $75.86 \%$, and VHS 1 Kalasan reached $72.30 \%$. (2) Edotel effectively develops student entrepreneurial attitudes.

Some developed attitudes, leadership and responsibility area prominently developed otherwise innovative attitudes could not effectively be developed through apprenticeship at the Edotel. The quantitative presentation of attitudes achievement for VHS 4 Yogyakarta is $80.33 \%$, VHS 6 Yogyakarta $62.07 \%$, and VHS 1 Kalasan is $69.23 \%$. (3) The 
self-report questionnaire present the entrepreneurship skills of the students is effective with the highest skills are conceptual and decision-making, while the lowest skills are time management and hotel technical skills.

In more detail, the quantitative of skills achievement for VHS 4 Yogyakarta is 68,85\%, VHS 6 Yogyakarta is 68,97\%, and VHS 1 Kalasan is $58,46 \%$. (4) The results of in-depth interviews to find what factors that hypothetically affect achievement of students in entrepreneurship in the internship program. It is found four factors: the family environment, social environment, personal ability, and students' industrial attachment experience.

At the stage of qualitative explanatory, the 18 students with the highest skore of entrepreneurship were interviewed. There were 13 students of the 18 have an entrepreneurial family background in various fields. All the students are living in the family home and the students often help their parents to work. The following protocols are example of interwiew trancript. RQ is researcher questions, and $\mathrm{R}$ is respondent. RQ1: "Is your parents' work? What kind of work? R.1, "ayah menjadi pelukis". The father as a painter; R.2. "ayah berwirausaha di bidang pembibitan dan penaman ikan dan ibu penjual emas". Her father is entrepreneur in seeding and cultivating fish and her mother is gold trader. R.3 "Ayah berwirausaha di bidang usaha elektronika and perekaman video". His father works as an electronic commerce business and video filming business, R.4. "Ayah bekerja menjadi staff engineering pada PT. Jaya Mix dan ibu bekerja menjahit". Father works as engineering staff at PT. Jaya Mix, mother works as a taylor. The protocols example provide evidence that family background contribute on shaping students' entepreneurship.

The student's social environment may also shape the student's entrepreneurship. Of the 18 students, the 17 students said that most of the community member around home are entrepreneur in various of fields. The following interview trancripts support this statement. RQ:"Do you live with the neighborhoods working as an entrepreneur? Are you actively involved in an organization at school or community? Have you ever been directly involved in an entrepreneurial activity in either school or community? R1. "ada \{tetangga\} kebanyakan sebagai penjual makanan, pedagang kelontong, dan penjual baju". There are mostly traders, food sellers, grocery stores and clothing merchants around home in which the respondent live. The respondent has been actively involved in laundry and in Edotel. R.1."Saya bekerja di usaha laundry waktu kelas 1 dan 3 untuk mencari konsumen laundry and di Edotel dan membuat prakarya untuk dijual". This respondent much experienced as entrepreneurs, since at year ten upto year 12, he learned how to find prospective customer for laundry at Edotel of VHS 4. He also experiended in making product and sell them to the consumers". R.2, said that their neighborhoods work as mushroom and fish seeding farmer. He said "tetangga saya banyak bekerja menanam jamur dan pembibitan ikan". He also said that in his family he used to be trained in entrepreneurship by helping parent to sell ice, bags, and help parents in the field of fish seed and as gold trader. These supports the previous principle that social environment will influence on student's enterpreneurship.
The students'personal ability influence the high acquisition of entrepreneurship. The 18 respondent have all been involved in business activities at Edotel and industrial attachment school program at the hotels. RQ: "do you have a skill in your field of expertise? Do you have confidence, self-autonomous, responsibility, leadership, and discipline. The following are some example of respondents' answer. R1. "sebagai porter dan front office, sebab ketika prakerin juga sebagai porter dan bagian front office". However the R1, "kurang percaya diri pada awalnya tetapi untuk yang akan datang akan mencoba lebih keras". R1, was in charge as a porter and front office when he has been in industrial attachment program so that he is confidence enough at front office or as a porter. However, he is independence and has leadership as he experienced in leading the group. R.2 experiences are difference from $\mathrm{R} 1$. He states that he is confidence in house keeping since his industrial attachment program was also in house keeping for 3 months. R4 feels confidence while working. He said "InshaAllah sudah mandiri tetapi harus tetap dibiasakan". R.4. said that "sejauh mungkin harus mampu bertanggungjawab dari hal yang kecil sampai yang hal yang besar". R4. Confidence in house keeping since he experienced in this field when he has been in industrial attachment program of the school. The conclusion can be made that student's experience in industrial attachment program will also contribute to the forming strudent's personal ability and will in turn be at higher readiness to be enterpreneur.

\section{B. Discussion}

To start discussing the result, table 2 is provided. Table 2 shows that Edotel in VHS 6 is the best in developing knowledge, while Edotel in VHS 4 earns the highest percentage for developing attitude.

Table 2. The Aggregate of Entrepreneurial Competence for Each Edotel of School.

\begin{tabular}{|l|c|c|c|}
\hline $\begin{array}{c}\text { Schools } \rightarrow \\
\downarrow \text { Aspects }\end{array}$ & VHS 4 & VHS 6 & $\begin{array}{l}\text { VHS } \\
\text { Kalasan }\end{array}$ \\
\hline Knowledges & $73.77 \%$ & $75,86 \%$ & $72,30 \%$ \\
\hline Attitudes & $80,33 \%$ & $62,07 \%$ & $69,23 \%$ \\
\hline Skills & $68,85 \%$ & $68,97 \%$ & $58,46 \%$ \\
\hline
\end{tabular}

The data from table 2 also shows that Edotel in VHS I Kalasan is the lowest interm of developing skills compared to the other two VHSs. Edotel in VHS 6 is the best to develop knowledge, Edotel in VHS 4 earns the highest percentage for attitude, while Edotel in VHS I Kalasan is the lowest in developing skills compared to the other two VHSs.

Knowledge in accommodation service, receptionist, reservation process, clerical procedure, and updating tourism industry information are the knowledge that mingt be acquired through Edotel intersnhip program. All Edotel activities in all three vocational schools have an impact in improving the knowledge of hospitality accomodation. Aspects of entrepreneurship attitudes of VHS 4 reached the highest percentage compared to the other two VHS, that is $89.33 \%$. While the skill aspect of VHS 1 Kalasan looks the lowest, that is $58,46 \%$. This indicates that Edotel at VHS 1 Kalasan has 
not had a significant impact on the development of entrepreneurship skills in hospitality.

Further investigation was the explanation of the quantitative results, and depth interview was conducted to find what factors might affect the development of enterpreneurship competence. In what way the factors might influence the students enterpreneuship.

The qualitative investigation has found that the factors that might affect the high-score of enterpreneurship competence are family environment, social environment, personal skills, and students industrial attachment experience. It has been found that 13 students from the 18 of subject, their family background is businessman. Another interesting finding is that the students' industrial attachment experience influenced the development of entrepreneurial attitudes. Industrial attachment is a field-based subject, i.e students working in industries or workplaces such as hotels or restaurants with the aim of providing insight into the world of work for students and entrepreneurial experience. So that, there is a possibility after students getting to know the industrial world, their entrepreneurial insight grows and begins to understand about the business world and entrepreneurship. These awareness then will possibly improve students' readiness of being enterpreneur.

\section{CONCLUSIONS}

Edotel has functioned as a agent of change to alter students mindset as job seeker into job provider. The Edotel has also a positive impact on the development of entrepreneurship competence of hospitality accommodation students. In more detail, at the aggregation Edotel's competence is able to develop students' knowledge, attitude, and skill of hospitality.

Edotel's internship program has been proven capable of developing enterpreneuship attitudes aspect especially on leadership and responsibility. Edotel has also had an impact on developing entrepreneurial skills in the hospitality, especially conceptual skills and decision-making skills. In other words, learning at Edotel can have a positive impact on developing entrepreneurship skills in the hospitality field.

Factors affecting the high entrepreneurship attitude of students are associated with family environment, social environment, personal ability, and industrial attachment experience.

However, there are limitation and weakness in this research, such as the use of a self-report questionnaire. The use of self report to measure skills in hospitality accommodation and attitudes toward the entrepreneurship of the hospitality accommodation is considered weakness. However, the use of performance test is not possible because of technical limitations and time contraint.

\section{B. Suggestions}

VHS 4 Yogyakarta, VHS 6 Yogyakarta, and VHS 1 Kalasan, can synchronize between subjects of entrepreneurship theory with learning in Edotel so that the learning process and objectives have interrelationship with each other. VHS parties build communication with the community, parents, and so that they also support school program. Industrial attachment program need to be improved in order to be alligned with the development of students' enterpreneurship in school.

\section{REFERENCES}

[1] National Council for Entrepreneurship Education, Toward a Theroy of Vocational Education. Columbus: NCRVE Pub., 2013.

[2] Djojonegoto, W. Pengembangan sumber daya manusia melalui sekolah menengah kejuruan. Jakarta: PT Jayakarta Agung Offset, 1998.

[3] Finch, C. R and Crunkilton, J. R. Curiculum Development in Vocational and Technical Education: Planning, Content, and Implementation, $5^{\text {th }}$ Ed. Boston: Allyn and Bacon, 1999.

[4] Djohar, A. "Pendidikan teknologi dan kejuruan" (Versi Electronic). Makalah Seminar disampaikan di Universitas Pendidikan Indonesia, Bandung: UPI, 2006.

[5] Hisrich, R. D., \& Peters, M. P. Entrepreneurship, New York: McGrawHill Co., 2002.

[6] Murtini, W. Kewirausahaan: pendekatan success story. Surakarta: Sebelas University Press, 2009.

[7] Kasmir, Kewirausahaan. Jakarta: PT. Raja Grafindo Persada, 2011.

[8] Wei, Y., \& Guo, W. Construction of the entrepreneurship education teachers based on the characteristics of business education level. Journal of International Educataion Studies, Vol. 3, No, 2; Mey 2010.

[9] K. Ernest., K., Matthew, S. K., \& Samuel, A.K. Towards entrepreneurial learning competencies: The perspective of built environment students. Journal Higher Education Studies; Vol. 5, No. 1; 2015.

[10] Morris, M. H., Webb, J. W., and Jun. F. Competency bassed perspective on enterpreneurship education: Conceptual and empirical insight. Journal of small business management, 51(3), pp. 352-369., 2013.

[11] Muhadi, F. X., \& Saptono, L. Jiwa Kewirausahaan Siswa SMK: Suatu Survei pada Tiga SMK Negeri dan Tujuh SMK swasta di D. I. Yogyakarta. Jurnal Widya Dharma, 16(1), 15-28, 2005.

[12] Hariyanto, V. L., Usman, H., Pardjono, P. The Implementation of Integrated Learning for developing the Entrepreneurship Readiness for the Students of Vocational High School Majoring in Architecture Engineering. Jurnal Pendidikan Vokasi Vol. 7, No. 2, p. 228-241; June 2017.

[13] Lastariwati, B. Model Pembelajaran Kewirausahaan Produktif EkRenFaTiHa Untuk Sekolah Menengah Kejuruan Program Studi Pariwisata Bidang Keahlian Tata Boga. Unpublished Disertation. Program Pascasarjana Universitas Negeri Yogyakarta, 2014.

[14] Direktorat PSMK, Petunjuk Teknis Tahun 2013 Bantuan Pembelajaran Kewirausahaan. Jakarta: Kemendikbud, 2013.

[15] Prosser, C. A., \& Quigley, T. H. Vocational Education in a Democracy. Chicago: American Technical Society, 1950.

[16] Khoiron, A. M. The Influence of Teaching Factory Learning Model Implementation to Students' Occupational Readiness. Jurnal Pendidikan Teknologi dan Kejuruan, 23(2), pp. 122-129, May 2016.

[17] Marini, C. K. Strategi Training Within Industry sebagai Upaya Peningkatan Kepercayaan Diri Siswa pada Mata Pelajaran Pengolahan Makanan Kontinental, Jurnal Pendidikan Teknologi dan Kejuruan, 22(4), pp. 410-423, Oktober 2015.

[18] Azwar, S. Penyusunan Skala Psikologi. Yogyakarta: Pustaka Pelajar Offset, 2010.

[19] R. K. Yin, Case Study Research: Design and Methods. London: Sage.

[20] M. B. Miles and A. M. Huberman, Qualitative Data Analysis: Expanded Sourcebook, 2nd ed. London: Sage. 